\title{
A Comparative Assessment of Self-Medication Between First And Second Year Medical Students of A Teaching Hospital In Dakshina Kannada, South India
}

\author{
Chetana Omkar ${ }^{1}$, Arun Ravindran ${ }^{2}$, Mohandas Rai ${ }^{3 *}$, Srinivas Bhat $\mathrm{U}^{4}$ \\ ' (Postgraduate, Department of Pharmacology, A.J. Institute of Medical Sciences, Mangaluru, India) \\ ${ }_{2}^{2}$ (Assistant Professor, Department of Pharmacology, A.J. Institute of Medical Sciences, Mangaluru, India) \\ 3*(Professor \& HOD, Department of Pharmacology, A.J. Institute of Medical Sciences, Mangaluru, India) \\ ${ }^{4}$ (Assistant Professor, Department of Pharmacology, A.J. Institute of Medical Sciences, Mangaluru, India)
}

\begin{abstract}
Self-medication is widely practiced among medical students and the influence of knowledge of medicines and diseases may contribute to this as the medical course progresses. This study was conducted to assess and compare the knowledge, attitude and practices towards self- medication between First year MBBS students and Second year of MBBS students in a tertiary care teaching hospital in Dakshina Kannada, South India.

cross-sectional descriptive study was conducted during October - November 2015 with a self-structured and pre-validated questionnaire. Study population consisted of two groups; Group I comprising First year MBBS students $(n=149)$, and Group II comprising MBBS students who had completed Second year MBBS course (n=198). Data were analyzed using SPSS Version 16.0. Comparison between the two groups was done using Chi square and Mann Whitney U tests. Awareness about Over the Counter medicines, Adverse Drug Reactions of medicines, generic and branded medicines was significantly higher in Group II. 88\% of respondents from Group I and 91 \% from Group II reported to have practiced self-medication atleast once in the previous year. The practice of self-medication was seen in both First year and Second year medical students, although Second Year students had better knowledge regarding this practice.
\end{abstract}

Keywords: Medical students, Self-medication, Teaching

\section{Introduction}

Osler once said, "The desire to take medicine is perhaps the greatest feature which distinguishes man from animals". Self-medication is a habitual practice which can be defined as "Obtaining and consuming drugs without the advice of a physician either for diagnosis, prescription or surveillance of treatment [1]."Selfmedication is practiced widely all over the world and it is considered as a part of self-care [2]. Self-medication has the ability to do good as well as harm the human beings since it involves the use of drugs. The World Health Organization (WHO) has appropriately pointed out that self-medication if practiced correctly can help in prevention and treatment of diseases that do not require medical consultation. Self-medication is also a cheaper alternative for treating common illnesses [3]. The practice of self-medication should always be based on authentic medical information; otherwise irrational use of drugs can not only cause increased resistance of pathogens, but can also lead to serious health hazards such as adverse drug reactions and prolonged morbidity and sometimes even death [2]. In developing countries, self-medication is a common practice as it provides a low-cost alternative for people who cannot afford the high cost of hospital services and also as many drugs are dispensed over the counter without prescription from a registered medical practitioner [4]. While selfmedicating, the individual should be aware of the benefits and risks of the medications used.

Self-medication is of great significance among medical students as in the future, they will have a major role in counselling the patients regarding this practice [5]. Upon commencement of the first year of their MBBS course, medical students usually do not differ from the general population of a similar age group, as far as the practice of self-medication is concerned. But upon completion of the second year of MBBS, the students may differ significantly from their first year counterparts, owing to an increased exposure to knowledge about diseases and drugs. This may further be compounded by an increased knowledge in Pharmacology of drugs, with the subject training completed by the end of second year of MBBS. An assessment of self-medication among medical students is prudent, especially their capacity to identify advantages and disadvantages of selfmedication [6].

Hence, the present study was conducted with the objective to assess and compare the knowledge, attitude and practices towards self- medication between first year MBBS beginner students and student who have completed second year of MBBS in a tertiary care teaching hospital in Dakshina Kannada, South India. 


\section{Materials And Methods}

The study was conducted using a cross sectional, questionnaire based design. The study was commenced following approval from the Institutional Ethics Committee of A. J. Institute of Medical Sciences \& Research Centre, Mangaluru (Ethical Clearance No. AJEC/REV/111/2015-16). The duration of the study was 2 months (October - November 2015). A self-structured, pre-validated questionnaire consisting of both openended and closed-ended questions were used. The questionnaire consisted of 4 sections. Section A included demographic details and section B, C \& D included questions on knowledge, attitude and practices towards selfmedication, respectively. 352 students were selected for the study based on universal sampling. Following informed consent, 347 medical students of A J Institute of Medical Sciences \& Research Centre were included in the study and divided into 2 groups [7].

Group I: 1st year MBBS students (1st Term)

Group II: 2nd year MBBS students (5th Term)

In keeping a previous study assessing self medication, certain operational terms were defined. Selfmedication was defined as the use of over-the-counter or prescription drugs, whether modern or traditional, for self-treatment, without prior consultation with a doctor. A doctor was defined as any person who is medically qualified to prescribe medications. It included practitioners of modern scientific medicine as well as practitioners of other healthcare systems. Medication was defined as any substance used for treatment or prevention of disease. It included modern scientific medications as well as medications from other healthcare systems [7]. All data pertaining to participants' details were kept strictly confidential. Data was expressed as counts and percentages. Statistical comparison of data between the two groups was done by Chi square \& Mann Whitney U test using SPSS version 16.0 and $p$ value less than 0.05 was considered statistically significant. Some of the questions had multiple options to choose from, therefore the sum total of percentages is not always $100 \%$.

\section{Results}

3.1 Demographic details of the students who participated in the study:

As shown in "Fig 1"

A) Gender frequency distribution

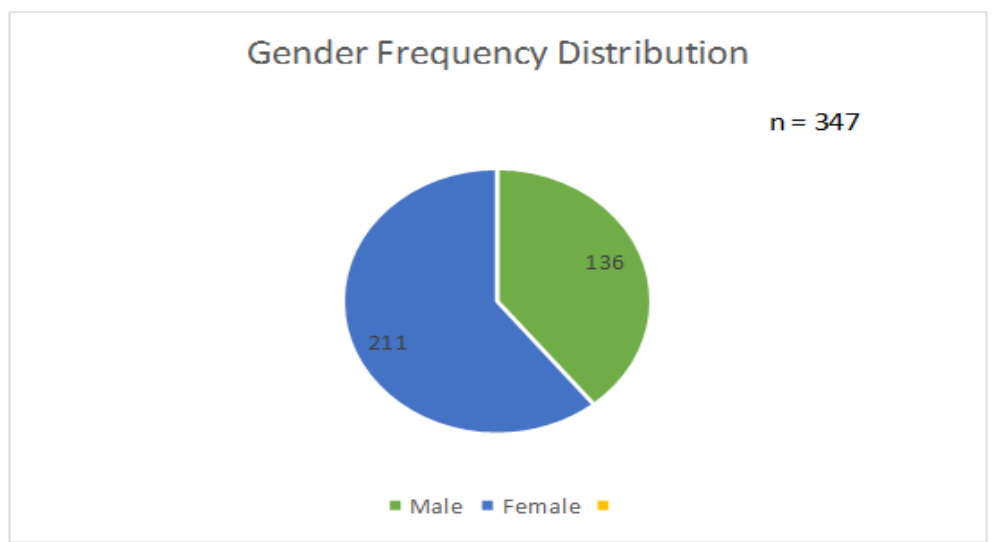

B) Frequency distribution based on age

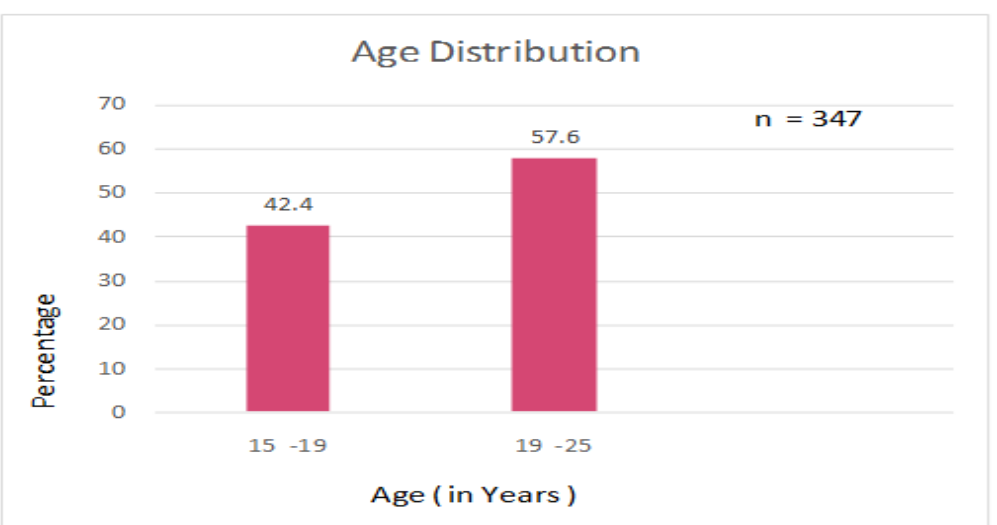

Figure 1: Demographic details of the students who participated in the study 
A) Gender frequency distribution B ) Frequency distribution based on age

\section{2 ) Questions assessing knowledge}

Questions assessing knowledge which were considerably important are shown in "TABLE 1".

Table 1: Number and Percentage of Respondents Who Answered "Yes" To Questions Assessing "Knowledge"regarding Self- Medication

\begin{tabular}{|l|l|l|l|}
\hline SL NO & \multicolumn{1}{|c|}{ Questions } & \multicolumn{1}{|c|}{$\begin{array}{l}\text { Number and Percentage of } \\
\text { students who answered "YES" }\end{array}$} \\
\cline { 3 - 4 } & & $\begin{array}{l}\text { GROUP I } \\
(\mathrm{n}=149)\end{array}$ & $\begin{array}{l}\text { GROUP II } \\
(\mathrm{n}=198)\end{array}$ \\
\hline 1 & $\begin{array}{l}\text { Self- medication carries the risk of using } \\
\text { wrong medicine/s for a particular } \\
\text { condition. }\end{array}$ & $131(87.9 \%)$ & $190(96.0 \%)$ \\
\hline 2 & $\begin{array}{l}\text { Severe side effects may result from self - } \\
\text { medication. }\end{array}$ & $89(59.7 \%)$ & $148(74.7 \%)$ \\
\hline 3 & $\begin{array}{l}\text { Antibiotics are the commonest class used } \\
\text { for self - medication. }\end{array}$ & $70(47.0 \%)$ & $104(52.5 \%)$ \\
\hline 4 & $\begin{array}{l}\text { Self-medication with antibiotics is a } \\
\text { common cause for antibiotic resistance. }\end{array}$ & $99(66.4 \%)$ & $159(80.3 \%)$ \\
\hline
\end{tabular}

All percentages are expressed in parentheses.

\section{3) Questions assessing Attitude}

Questions assessing attitude which were considerably important are shown in "TABLE 2".

Table 2: Number and Percentage of Respondents Who Answered "Yes" To Questions Assessing "Attitude towards Self- Medication"

\begin{tabular}{|l|l|l|l|}
\hline SL NO & Questions & $\begin{array}{l}\text { Number and Percentage of students who } \\
\text { answered "YES" }\end{array}$ & $\begin{array}{c}\text { GROUP II } \\
n=198\end{array}$ \\
\cline { 3 - 4 } & & $\begin{array}{l}\text { GROUP I } \\
\mathrm{n}=149\end{array}$ & $56(28.3 \%)$ \\
\hline 1 & $\begin{array}{l}\text { Self- medication is a good } \\
\text { practice }\end{array}$ & $67(45.0 \%)$ & $157(79.3 \%)$ \\
\hline 2 & $\begin{array}{l}\text { Previous experience of treating } \\
\text { similar illness usually promotes } \\
\text { self- medication }\end{array}$ & $124(83.2 \%)$ & $182(91.9 \%)$ \\
\hline 3 & $\begin{array}{l}\text { Self-medication in our society } \\
\text { is promoted by the easy } \\
\text { availability of medicines/ drugs }\end{array}$ & $128(85.9 \%)$ & $47(23.7 \%)$ \\
\hline 4 & $\begin{array}{l}\text { We should favour self- } \\
\text { medication for economically } \\
\text { weak persons }\end{array}$ & $66(44.3 \%)$ & $152(76.76 \%)$ \\
\hline 5 & $\begin{array}{l}\text { Pharmacology course plays a } \\
\text { mojor role in practice of self - } \\
\text { medication? Does it help in } \\
\text { safe practice of self-medication } \\
?\end{array}$ & $69(46.30 \%)$ & \\
\hline
\end{tabular}

All percentages are expressed in parentheses.

\section{4) Questions assessing Practice}

Questions assessing attitude which were considerably important are shown in "TABLE 3".

Table 3 : Number and Percentage of Respondents Who Answered "Yes" To Questions Assessing "Practices Of Self - Medication"

\begin{tabular}{|l|l|l|l|}
\hline S1 & Questions & \multicolumn{2}{|l|}{$\begin{array}{l}\text { Number And Percentage Of } \\
\text { Students Who Answered "Yes" }\end{array}$} \\
\cline { 3 - 4 } & & $\begin{array}{l}\text { Group I } \\
(\mathrm{N}=149)\end{array}$ & $\begin{array}{l}\text { Group Ii } \\
\text { (N = 198) }\end{array}$ \\
& & & \\
\hline 1 & Have Taken Self-Medication Before? & $131(87.9 \%)$ & $180(90.9 \%)$ \\
\hline
\end{tabular}


A Comparative Assessment Of Self-Medication Between First And Second Year....

\begin{tabular}{|l|l|l|l|}
\hline 2 & $\begin{array}{l}\text { How Many Times Did You Treat Yourself } \\
\text { With Self -Medication In The Past 1 Year }\end{array}$ & \\
\hline A ) & More Than 5 Times Per Year & $37(28.2 \%)$ & $64(35.6 \%)$ \\
\hline B $)$ & Every Few Months & $26(19.8 \%)$ & $35(19.4 \%)$ \\
\hline 3 & $\begin{array}{l}\text { What Were The Most Common Reasons For } \\
\text { Self-Medication? }\end{array}$ & & \\
\hline A) & Convenience & $118(79.1 \%)$ & $156(78.7 \%)$ \\
\hline B) & Cost Saving & $26(19.8 \%)$ & $18(9.09 \%)$ \\
\hline 4 & $\begin{array}{l}\text { Most Common Complaints For Which } \\
\text { Students Self-Medicated In Past 1 Year? }\end{array}$ & & \\
\hline A) & Fever & $87(58.38 \%)$ & $134(67.6 \%)$ \\
\hline B) & Runny Nose & $76(51 \%)$ & $100(50.5 \%)$ \\
\hline C) & Cough & & $89(44.94 \%)$ \\
\hline 5 & $\begin{array}{l}\text { Most Common Reasons Given For Awareness } \\
\text { Of The Dosage For Self- Medication: }\end{array}$ & $52(34.89 \%)$ & $63(31.81 \%)$ \\
\hline A ) & By Consulting A Pharmacist & $47(31.54 \%)$ & $53(26.76 \%)$ \\
\hline B $)$ & From Their Previous Experience & $43(28.85 \%)$ & $53(26.76 \%)$ \\
\hline C $)$ & By Consulting Family Members / Friends & $35(26.5 \%)$ & $41(22.3 \%)$ \\
\hline 6 & $\begin{array}{l}\text { Did They Self-Medicate With } \\
\text { Herbal/Ayurvedic Medication Before? }\end{array}$ & $2(1.5 \%)$ & $11(6.0 \%)$ \\
\hline 7 & $\begin{array}{l}\text { Did They Experience Any Side Effect After } \\
\text { Taking Self-Medication? }\end{array}$ & & \\
\hline All percentages are expressed in parentheses & & \\
\hline
\end{tabular}

All percentages are expressed in parentheses.

3.5 ) Mann Whitney U test for Knowledge and Attitude Section:

\section{Knowledge}

P Value is significant $(<0.001)$. Hence knowledge of Second year MBBS students was found to be better than First year MBBS students.

Attitude- P Value $>0.05$. So the difference in attitude of both First and Second year MBBS students was not significant.

\section{Discussion}

Both First as well as Second year MBBS students had good knowledge regarding the advantages and disadvantages of self-medication. Majority of them felt self-medication as time-saving and economical, doing away with the need to go to a doctor for minor illness and providing quick, easy and convenient relief. These perceptions are similar to those reported by the WHO that self-medication provides a cheaper and convenient alternative for treating common minor illnesses $[8,9]$. These are important factors favouring self-medication and have been reported in other studies $[2,10]$. Length of waiting time and cost for medical consultation has been identified as one of the triggering factors for self-medication [11]. The most important disadvantages of self-medication are fear of adverse drug reactions and risk of using a wrong drug (fear of the unknown), results similar to those found in an earlier study. [2]

The majority of the students had a positive attitude towards self-medication, saying that it is a good practice. In general, the students felt that medical knowledge was making them more cautious about selfmedication and many would prefer to seek a prescription. Some were afraid of adverse drug reactions, while others felt they would discourage self-medication. This shows educating public about health benefits and spreading awareness are important for making self-medication safe and useful. This has also been noted by the WHO [8] and by Hughes et al [12]. Recently it was shown that increasing medical knowledge affects the prescribing behaviour of medical students [13]. Hence it was decided to investigate further whether increasing medical knowledge and influence of studying Pharmacology also affects the knowledge, attitude and practice of self-medication among medical students.

In our study, $87.9 \%$ of First year Medical students and $90.9 \%$ of Second year students practice selfmedication. Second year students practice self-medication more often. Previous Studies on self-medication have reported various prevalence figures, ranging from $26.2 \%$ [11] to as high as $92 \%$ [14]. The commonest illnesses that led to self-medication in this study were usually self-limiting 'minor illnesses' that have been widely reported in studies on self-medication as the most common indications $[2,10]$. This has significance, because minor illness like runny nose, cold, cough and fever are usually recurrent and a person with previous experience may be exposed to the knowledge of medicines used for these conditions. In many studies, Analgesics have been reported to be the most commonly used group of drugs for self-medication [2, 15]. Our study also found similar results. Among the analgesics, paracetamol was the most commonly used drug. This correlates well with fever being the most common indication for self-medication.

Paracetamol is widely used for headache, fever and body aches and pains. The use of antimicrobials/ antibiotics has been very limited in this study population. The finding that is most alarming is many the First- 
year medical students who are beginning to be exposed to medical information and have a very limited medical knowledge also practice self medication.

Mann-Whitney U test showed significant difference in scores of knowledge section between First year and Second year MBBS students, which shows that Second year MBBS students have better knowledge about self medication. However attitude section score was not significant among these two study groups.

\section{Conclusion}

Second Year MBBS students have a better knowledge about certain aspects of self-medication which is because of the influence of medical training and they practice medication more often. But even first year MBBS students who are not exposed to the knowledge of drugs and disease are well aware about self-medication. The two important factors which encouraged self- medication in these students were minor illness and prior experience with drug. The majority of students supported self -medication practices. The incidence and prevalence of self -medication is high which could be because of their subject knowledge and medical background. Hence students need to be counselled about advantages and limitations of self- medication so that they practice self-medication even more effectively.

\section{Acknowledgement}

The authors would like to thank the First and Second year medical students of A J Institute of Medical Sciences \& Research Centre, Mangaluru for their enthusiastic co-operation.

\section{Conflict Of Interest}

The authors declare that they have no conflict of interest.

\section{References}

[1]. Montastruc JL, Bagheri H, Geraud T, Lapeyre-Mestre M, Pharmacovigilance of self- medication, Therapie, 52, 1997, 105-110.

[2]. Hughes CM, McElnay JC, Fleming GF. Benefits and risks of self-medication. Drug Saf, 24, 2001, $1027-37$.

[3]. World Health Organization: The role of the pharmacist in self care and self- medication. Available from: http://www.apps.who.int/medicinedocs/pdf/whozip32e/whozip32e.pdf [Last accessed on 2016 Apr 23].

[4]. Hussain S, Malik F, Hameed A, Riaz H. Exploring healthseeking behaviour, medicine use and self-medication in rural and urban Pakistan. Southern Med Rev, 3:32-4.

[5]. Banerjee I, Bhadury T. Self-medication practice among undergraduate medical students in a tertiary care medical college, West Bengal. J Postgrad Med, 58, 2012, 127-31.

[6]. Sontakke SD et al. Int J Biol Med Res, 2(2), 2011, 561-564.

[7]. James H, Handu S S et al. Evaluation of the Knowledge, Attitude and Practice of Self-Medication among First-Year Medical Students. Med Princ Pract, 15, 2006, 270-275.

[8]. World Health Organization. Report of the WHO Expert Committee on National Drug Policies 1995. http://www.who.int/medicines/ library/dap/who-dap-95-9/who-dap-95.9.shtml.

[9]. Kafle KK, Gartulla RP. Self-medication and its impact on essential drugs schemes in Nepal:a sociocultural research project 1993 .

[10]. Shankar PR, Partha P, Shenoy N. Self-medication and non-doctor prescription practices in Pokhara valley, Western Nepal: a questionnaire- based study. BMC Family Practice, 3, 2002, 17.

[11]. Martins AP, Miranda AC, Mendes Z, Soares MA, Ferreira P, Nogueira A. Self-medication in a Portuguese urban population: a prevalence study. Pharmacoepidemiol Drug Saf , 11, 2002,409-414.

[12]. Hughes CM: Monitoring self-medication. Expert Opin Drug Saf, 2, 2003,1-5.

[13]. Al Khaja KAJ, Handu SS, James H, Mathur VS, Sequeira RP. Assessing prescription writing skills of pre-clerkship medical students in a problem-based learning curriculum. Int J Clin Pharmacol Ther, 43, 2005, 429-435.

[14]. Abahussain E, Matowe LK, Nicholls PJ.Selfreported medication use among adolescents in Kuwait. Med Princ Pract, 14, 2005, $161-164$

[15]. Vedrana AV, Vladimir T, Zdravko L. Content of home pharmacies and self-medication practices in households of pharmacy and medical students in Zagreb, Croatia: findings in 2001 with a reference to 1977. Croat Med J, 46, 2005, 74-80. 